\title{
Current and Emerging Reconstituted HDL-apoA-I and HDL-apoE Approaches to Treat Atherosclerosis
}

\author{
Eftaxia-Konstantina Valanti ${ }^{1,2}$, Katerina Dalakoura-Karagkouni ${ }^{3}$ and Despina Sanoudou $1,2,4, * \mathbb{B}$ \\ 1 Clinical Genomics and Pharmacogenomics Unit, 4th Department of Internal Medicine, “Attikon” Hospital, \\ Medical School, National and Kapodistrian University of Athens, 11527 Athens, Greece; \\ evalanti@bioacademy.gr \\ 2 Molecular Biology Division, Biomedical Research Foundation of the Academy of Athens, \\ 11527 Athens, Greece \\ 3 Department of Biochemistry, University of Crete, Medical School, 71003 Heraklion, Greece; \\ medp2011666@med.uoc.gr \\ 4 Center for New Biotechnologies and Precision Medicine, Medical School, National and Kapodistrian \\ University of Athens, 11527 Athens, Greece \\ * Correspondence: dsanoudou@med.uoa.gr
}

Received: 3 August 2018; Accepted: 27 September 2018; Published: 3 October 2018

check for updates

\begin{abstract}
Atherosclerosis affects millions of people worldwide. However, the wide variety of limitations in the current therapeutic options leaves much to be desired in future lipid-lowering therapies. For example, although statins, which are the first-line treatment for coronary heart disease (CHD), reduce the risk of cardiovascular events in a large percentage of patients, they lead to optimal levels of low density lipoprotein-cholesterol (LDL-C) in only about one-third of patients. A new promising research direction against atherosclerosis aims to improve lipoprotein metabolism. Novel therapeutic approaches are being developed to increase the levels of functional high density lipoprotein (HDL) particles. This review aims to highlight the atheroprotective potential of the in vitro synthesized reconstituted HDL particles containing apolipoprotein $\mathrm{E}$ (apoE) as their sole apolipoprotein component (rHDL-apoE). For this purpose, we provide: (1) a summary of the atheroprotective properties of native plasma HDL and its apolipoprotein components, apolipoprotein A-I (apoA-I) and apoE; (2) an overview of the anti-atherogenic functions of rHDL-apoA-I and apoA-I-containing HDL, i.e., natural HDL isolated from transgenic Apoa1 $^{-/-} \times \mathrm{Apoe}^{-/-}$mice overexpressing human apoA-I (HDL-apoA-I); and (3) the latest developments and therapeutic potential of HDL-apoE and rHDL-apoE. Novel rHDL formulations containing apoE could possibly present enhanced biological functions, leading to improved therapeutic efficacy against atherosclerosis.
\end{abstract}

Keywords: atherosclerosis; lipoprotein metabolism; reconstituted HDL; apolipoprotein A-I; apolipoprotein E

\section{Introduction}

Cardiovascular disease (CVD) is the leading cause of morbidity and mortality worldwide [1]. Coronary heart disease (CHD) is the most common type of CVD and is caused by atherosclerotic occlusion of the coronary arteries [2]. Coronary heart disease causes approximately 7.2 million deaths worldwide, while the annual cost of CHD in the USA alone has been estimated to be over $\$ 10$ billion $[1,2]$. Current projections estimate that the prevalence of $\mathrm{CHD}$ along with the associated cost of treatment will increase by almost $18 \%$ and $43 \%$, respectively, by the year 2030 [2].

Atherosclerosis develops over the course of decades as a result of endothelial dysfunction, vascular inflammation, lipid and fibrous component accumulation along with gradual thickening of the blood 
vessel walls [3-5]. Extensive research over the years has led to the development of several low density lipoprotein cholesterol (LDL-C)-lowering therapeutic approaches, including statins, inhibitors of cholesteryl ester transfer protein (CETP), inhibitors of intestinal cholesterol absorption (ezetimibe) and inhibitors of proprotein convertase subtilisin/kexin type 9 (PCSK9) [6-8]. However, despite their significant benefits in the clinical setting, each treatment has considerable limitations, such as considerable patient-to-patient variability in lowering LDL-C, which leaves a significant number of patients with suboptimal treatment options [9-15]. For example, statins, which are the first line LDL-C lowering treatment in CHD patients, lead to optimal LDL-C levels in only $37 \%$ of patients [16], while the residual cardiovascular risk despite considerable LDL-C reduction by statin therapy is estimated at $12-22 \%$ [17-20].

New, potentially better targeted approaches are being pursued, aiming to prevent the development and progression of atherosclerosis by targeting atherogenic mechanisms at the level of the arterial wall, which ranges from lipid accumulation and endothelial dysfunction to inflammation and plaque stabilization [21-24]. One promising research avenue lies in high density lipoprotein (HDL) metabolism and functionality as a means to treat, or ideally prevent, atherosclerosis $[7,21,25-30]$. The failure of several HDL-C raising drugs to decrease the incidence of recurrent cardiovascular risk in CHD patients, despite raising HDL-C [31], has led to the conclusion that HDL functionality is more important that HDL-C levels per se in atheroprotection $[7,25,29,32]$.

\section{The Atheroprotective Properties of HDL, apoA-I and rHDL-apoA-I}

HDL functionality is dependent on its apolipoprotein and lipid composition. Furthermore, it has multiple atheroprotective features, including reverse cholesterol transfer, anti-inflammatory, anti-oxidative, anti-thrombotic, vasodilatory and re-endothelialization related properties [26,33-35]. Numerous studies in animal models of atherosclerosis and human patients have shown that HDL inhibits the development of atherosclerosis and even promotes atherosclerotic plaque regression $[33,36]$. The anti-atherogenic functions of HDL have been attributed to apolipoprotein A-I (apoA-I) to a certain extent, which is the major apolipoprotein component of HDL that participates in the biogenesis, remodeling and signaling of HDL [33]. Studies in apolipoprotein E (apoE) or low density lipoprotein receptor (LDLR) deficient mice have shown that hepatic overexpression of human apoA-I leads to $70 \%$ regression of pre-existing aortic atherosclerotic lesions [37]. Consistent with these findings, double deficient mice for apoA-I and LDLR which were fed an atherogenic diet developed more severe atherosclerosis compared to the apoA-I deficient animals [38]. The anti-atherosclerotic effects of apoA-I have been associated with its ability to promote cholesterol efflux from macrophage-derived foam cells in vivo via interactions with the ATP binding cassette subfamily A member 1 (ABCA1) and ATP binding cassette subfamily G member 1 (ABCG1) transporters [37,39]; to reduce arterial wall inflammation [40-42]; and to preserve endothelium integrity [43-46]. Due to these atheroprotective properties of HDL and apoA-I, extensive research efforts have been geared towards the development of HDL and apoA-I targeted therapeutic approaches increasing the levels of functional HDL particles $[7,25,29,32,47]$. Ongoing clinical trials involve apoA-I and HDL mimetic peptides, apoA-I transcriptional upregulators, de-lipidated HDL as well as in vitro synthesized reconstituted forms of discoidal HDL particles containing phospholipids and apoA-I as the sole apolipoprotein (rHDL-apoA-I) $[7,25,29,47,48]$. This review is focused specifically on the developments of rHDL-based therapeutic approaches.

The infusion of rHDL-apoA-I particles, which are designed to favor interactions with the ABCA1 transporter, constitute a direct approach to elevate plasma levels of apoA-I and discoidal pre- $\beta$ HDL particles, resulting in an increase in mature spherical HDL particles and subsequently HDL-C levels [25,49-53]. Moreover, rHDL-apoA-I infusion therapies enhance the atheroprotective functions of HDL, such as cellular cholesterol efflux capacity, while minimizing its off-target effects $[11,50,51,54]$. A number of rHDL-apoA-I formulations containing either native wild type apoA-I purified from human plasma (CSL-111, CSL-112, CER-001) or apoA-I Milano (MDCO-216), 
which is a genetic variant of apoA-I whose carriers experience reduced CVD risk despite low HDL-C levels [55], complexed with phospholipids have progressed from in vivo studies to clinical trials [11,50,52-54,56-58]. In pre-clinical studies, these various rHDL-apoA-I agents have been shown to promote the regression of coronary atherosclerotic plaques in vivo by increasing ABCA1-mediated cholesterol efflux from macrophages $[59,60]$. However, despite the promising in vivo findings as MDCO-216 [52], CSL-111 [56] and CER-001 [53] infusions increased apoA-I plasma levels and enhanced HDL-C cholesterol efflux capacity in healthy volunteers and CHD patients, they failed to achieve a significant regression in coronary atherosclerosis when tested in clinical trials [11,53,56,57]. In contrast, the infusions of CER-001 in patients with familial hypoalphalipoproteinemia and homozygous familial hypercholesterolemia led to atherosclerosis regression, with CER-001 currently being assessed in a phase III clinical trial [61,62]. Further clinical development of MDCO-216 and CSL-111 has been halted due to prohibitive production costs and adverse effects, respectively, combined with their failure to demonstrate a beneficial effect at the clinical level $[11,25,53,57]$. CSL-112 is a promising rHDL infusion therapy consisting of purified native human apoA-I combined with phosphatidylcholine, which has a reduced lipid/apoA-I ratio compared to CSL-111 [25]. Numerous phase I and II clinical trials in healthy volunteers [54] and patients with stable atherosclerotic CHD [50] or after an acute myocardial infraction [58] have demonstrated that CSL-112 enhances the levels of apoA-I and pre- $\beta$ HDL, induces a marked increase in cholesterol efflux capacity and is well tolerated with no evidence of liver toxicity. Despite the favorable clinical trial data, the potential of CSL-112 in reducing major adverse cardiovascular events in high-risk acute coronary syndrome patients remains to be determined in the large phase III AEGIS-II study that is expected to be concluded in 2022 [11].

\section{The Atheroprotective Functions of apoE}

Based on the therapeutic potential of rHDL-apoA-I formulations, the development of additional novel rHDL agents with different apolipoprotein/lipid compositions and enhanced atheroprotective activities holds promise for CHD patients [25,51]. Reconstituted HDL particles containing apoE (rHDL-apoE), which is an apolipoprotein that has pleiotropic atheroprotective functions [48,63], are one of the new rHDL agents under investigation.

Apolipoprotein E is a 34-kDa polymorphic glycoprotein largely secreted by the liver although it can also be locally produced by macrophages in atherosclerotic lesions [64]. The most common isoforms of apoE are apoE2, apoE3 and apoE4, which are the products of three different alleles at a single gene locus [63]. The apoE3 (Cys112/Arg158) is considered to be the most frequently encountered form of apoE [63]. The rarest variant, ApoE2 (Cys112/Cys158), is associated with increased levels of triglyceride-rich lipoproteins (TRLs) and Type III hyperlipoproteinaemia [65,66], while apoE4 (Arg112/Arg158) is associated with increased LDL-C levels [65-68].

Numerous pre-clinical and clinical studies have demonstrated the pleiotropic anti-atherogenic properties of apoE. The majority of these studies evaluated the atheroprotective functions of all three apoE isoforms (apoE2, apoE3 and apoE4), whereas others focused specifically on apoE3, since it appears to have more beneficial effects as discussed below. ApoE is a component of TRLs and promotes the LDLR dependent hepatic clearance of TRL remnants from the circulation [63]. Moreover, apoE stimulates the hepatic clearance of chylomicron remnants through its binding to the LDL receptor related protein (LRP) or the heparan sulfate proteoglycan (HSPG) receptor [69,70]. Dominant mutations have been identified in apoE that affect its interaction with the LDLR and are associated with higher plasma cholesterol levels, leading to hypertriglyceridemia in mice and type III hyperlipoproteinaemia in humans $[63,71]$. Consistent with these findings, a homozygous familial apoE deficiency in humans has been associated with a pro-atherogenic lipoprotein profile and atherosclerotic disease [72]. Similarly, apoE knockout $\left(\mathrm{Apoe}^{-/-}\right.$) mice are hypercholesterolemic due to impaired hepatic clearance of TRL remnants, which leads to the development of atherosclerosis even when the mice are fed a low fat 
diet $[71,73]$. In contrast, the hepatic overexpression of human apoE3 induced atherosclerosis regression in Apoe $^{-/-}$mice [74].

In addition to its role in TRL clearance, apoE stimulates hepatic very low density lipoprotein (VLDL) and triglyceride secretion and thus participates in the homeostasis of plasma cholesterol and triglyceride levels [75]. Importantly, apoE induces reverse cholesterol transport from peripheral tissues to the liver [63]. Numerous studies have demonstrated that apoE stimulates cholesterol efflux from macrophages and thus prevents foam cell formation and atherogenesis [76-78]. ApoE3 has been associated with higher cholesterol efflux capacity from human monocyte-derived macrophages compared to apoE2 and apoE4 [76]. HDL isolated from Apoe ${ }^{-/-}$mice demonstrated decreased cholesterol efflux capacity from mouse peritoneal macrophages although this was restored to normal by the administration of exogenous apoE [77]. Similarly, the expression of human apoE3 in macrophages increased the cholesterol efflux capacity from the arterial wall of Apoe ${ }^{-/-}$mice and limited the development of atherosclerosis [78]. Moreover, apoE can provide protection from atherosclerosis by promoting the in vivo biogenesis of functional spherical apoE-containing HDL particles (HDL-apoE) with the participation of ABCA1 and LCAT (lecithin-cholesterol acyltransferase) independently of apoA-I $[79,80]$. It has been shown that these HDL-apoE particles can be produced from transgenic Apoa $1^{-/-}$or double deficient Apoe ${ }^{-/-} \times$Apoa1 $^{-/-}$mice overexpressing human apoE, which accounts for at least some of the atheroprotective properties of apoE, as discussed below $[79,80]$. Finally, apoE activates the enzymes involved in lipoprotein metabolism, such as hepatic lipase (HL), CETP and LCAT. Thus, it enhances phospholipid hydrolysis in HDL, lipid exchange between VLDL and HDL and conversion of discoidal to spherical mature HDL particles [81-83].

Interestingly, several biological functions of apoE that are not directly related to lipid metabolism and transport also contribute to its anti-atherogenic role, such as its anti-inflammatory, anti-oxidative, anti-thrombotic and endothelial repair related properties [84-90]. Macrophage-derived apoE has been shown to suppress the activation of human umbilical vein endothelial cells (HUVECs) by inhibiting the expression of vascular cell adhesion molecule 1 (VCAM-1) and stimulating intracellular nitric oxide (NO) production $[84,85]$. In accordance with these findings, it has been shown that apoE3 binding to the ApoER2 receptor attenuates monocyte adhesion to bovine aortic endothelial cells (BAECs) [86]. Interestingly, a recent study showed that apoE expression in the monocytes and macrophages of hypomorphic apoE mice deficient in LDLR expression (Apoe ${ }^{\mathrm{h} / \mathrm{h}} \mathrm{LDLR}^{-/-}$mice) attenuated nuclear factor kappa B (NF-kB)-dependent inflammation and atherosclerosis by enhancing cellular miR-146a levels [91]. Moreover, apoE exerts anti-inflammatory actions by inhibiting the activation and proliferation of $\mathrm{T}$ lymphocytes [87] as well as by suppressing the migration and proliferation of smooth muscle cells induced by oxidized LDL [88]. In addition, apoE can inhibit lipoprotein oxidation and platelet aggregation and may thereby prevent the accumulation of oxidized LDL on the arterial wall as well as thrombus formation on atherosclerotic lesions $[89,90]$. Finally, the effect of apoE on endothelial cell functions contributes to its anti-atherogenic role [86,92]. It has been shown that the binding of apoE3 to ApoER2 induces BAEC migration and carotid artery re-endothelialization in mice through the stimulation of NO release [86]. Furthermore, apoE3 also protected HUVECs from apoptosis by suppressing the activation of caspases 3 and 7 [92].

At the clinical level, apoE synthetic mimetic peptides have been studied in phase I and phase II trials to investigate if they significantly reduce plasma cholesterol levels, with Ac-hE18A-NH2 having been licensed under the trade name AEM-28 [48,93-96]. Their effect against atherosclerosis is now under investigation [48].

\section{Advantages and Therapeutic Potential of apoE, HDL-apoE3 and rHDL-apoE3}

Based on the aforementioned findings, apoA-I and apoE appear to provide protection from atherosclerosis largely through similar functions, including the cholesterol efflux capacity, the anti-inflammatory, anti-oxidative and anti-thrombotic functions as well as their re-endothelialization and plaque stabilizing related properties. However, numerous studies have 
indicated that the ability of apoE to provide protection from atherogenesis appears to be more pronounced than that of apoA-I [96-99]. Indeed, in contrast to apoE deficiency, the deficiency of apoA-I does not cause atherosclerosis in mice by itself $[96,97]$. For example, Apoe ${ }^{-/-}$mice who were fed a high fat, high cholesterol Western-type diet developed atherosclerosis within 8 to 10 weeks $[96,100,101]$. Atherosclerotic lesions were also observed in Apoe ${ }^{-/-}$mice consuming a low fat, low cholesterol chow diet as early as 10 to 12 weeks of age $[73,96,101]$. On the contrary, no atherosclerotic lesions were evident in Apoa1 ${ }^{-/-}$mice when fed normal chow or even atherogenic diets for 20 weeks [97]. Likewise, although mice that were deficient in the HDL receptor SR-BI (scavenger receptor class B type I) $\left(\mathrm{SR}^{-\mathrm{BI}^{-/}}{ }^{-}\right)$and received a Western-type diet for 20 weeks developed atherosclerosis [100,102], the double deficient Apoe ${ }^{-/-} \times \mathrm{SR}-\mathrm{BI}^{-/-}$mice, which expressed the endogenous apoA-I, developed severe atherosclerotic lesions as early as 4 to 5 weeks of age when fed a standard chow diet [98-100]. Notably, these double knockout mice exhibited an early onset of occlusive atherosclerotic CHD, spontaneous myocardial infarctions, severe cardiac dysfunction and death at a young age (8 weeks) [99]. On the contrary, no atherosclerotic lesions were detected in SR-BI ${ }^{-/-}$mice at four to seven weeks of age when fed a normal chow diet [98]. Consistent with the above findings that suggest a more profound effect of apoE compared to apoA-I in terms of atheroprotection, the Ac-hE18A-NH2 apoE mimetic peptide was shown to be more effective than the $4 \mathrm{~F}$ ApoA-I mimetic in reducing the formation of atherogenic lesions in Apoe ${ }^{-/-}$mice [96]. Additionally, the anti-inflammatory properties of Ac-hE18A-NH2 were reported to be superior to those of $4 \mathrm{~F}$ [97].

The more profound effect of apoE compared to apoA-I on atheroprotection could at least partly be attributed to certain unique properties of apoE [79]. Unlike apoA-I, apoE can promote hepatic clearance of atherogenic TRL remnants from the circulation, influence hepatic VLDL secretion and activate lipoprotein metabolism related enzymes, which has been discussed above [63,75,81-83]. Furthermore, HDL-apoE particles are characterized by significant structural and functional differences compared to apoA-I-containing HDL (HDL-apoA-I) particles $[79,80]$ and could therefore contribute to the enhanced atheroprotective effects of apoE. Although HDL-apoE particles have been studied to a limited extent, the preliminary results seem to be promising $[79,80,96-99,103]$. For example, in contrast to Apoe (- $^{-}$ mice which develop atherosclerosis at a young age [96], Apoa ${ }^{-/-}$mice do not develop atherosclerosis when fed normal or atherogenic diets [97]. The possible explanations for these observations include a compensatory role of apoE through its multiple atheroprotective functions, including the formation of HDL-apoE particles that could provide protection from atherosclerosis [79]. Consistent with this notion, in the absence of apoE, neither the atheroprotective HDL-apoE particles can be formed nor the atherogenic TRL remnants can be cleared [79]. For instance, the HDL particles derived from the SR-BI ${ }^{-/-} \times \mathrm{Apoe}^{-/-}$mice, which lacked apoE, failed to protect the endothelium from atherosclerosis $[79,99]$. Additionally, the impaired TRL remnant clearance dramatically accelerated atherosclerosis in these mice at four to five weeks of age [99].

A recent study shed light on the distinct atheroprotective properties of HDL-apoE compared to HDL-apoA-I [80]. In specific, in double deficient Apoe ${ }^{-/-} \times$Apoa1 $^{-/-}$mice, the expression of either human apoE3 or apoA-I led to the formation of HDL-apoE3 or HDL-apoA-I particles, which differed in size, apolipoprotein and lipid content as well as HDL functionality [80]. Regarding the apolipoprotein content, apoE3 expression led to the exclusive recruitment of apoC-I on HDL, thus promoting the formation of apoC-I-containing HDL [80]. In contrast, the expression of apoA-I resulted in the formation of HDL particles containing primarily apoA-II and apoC-III [80]. The lipid composition was also different in that the synthesized HDL-apoA-I contained elevated levels of phospatidylserine and phosphatidylglycerol, while the levels of phosphatidylinositol and phosphatidic acid were comparable between HDL-apoA-I and HDL-apoE3 [80]. Importantly, the structural differences between those particles resulted in functionally distinct HDL subpopulations [80]. HDL-apoE3 presented a markedly reduced anti-oxidant potential in vitro and decreased ABCG1-mediated cholesterol efflux capacity from macrophages in vivo [80]. However, HDL-apoE3, but not HDL-apoA-I, reduced TNF $\alpha$ release 
from macrophages, suggesting that the anti-inflammatory effects of HDL-apoE3 are independent of the presence of apoA-I, while those of HDL-apoA-I are dependent on apoE3 expression [80].

The summary of these findings supports a heightened atheroprotective potential for HDL-apoE3 and consequently, a noteworthy potential in the clinical setting. Preliminary evidence towards this direction has showed that rHDL-apoE interacts with SR-BI and promotes cholesterol efflux [103]. However, further pre-clinical and future clinical studies are needed to demonstrate the potential of rHDL-apoE as a novel therapy for atherosclerosis. Our team is now focusing on the molecular, cellular and in vivo effects of rHDL-apoE with promising results to date (unpublished data).

\section{Conclusions}

A number of rHDL formulations have been developed using apoA-I to enhance the atheroprotective functions of $\mathrm{HDL}$, with the ultimate goal to treat or even prevent atherosclerosis. However, with the exception of CSL-112, these agents were unable to demonstrate a clinical benefit in CHD patients. Nowadays, the encouraging results of CSL-112 pre-clinical and clinical studies, along with knowledge on the pleiotropic atheroprotective properties of apoE3 and the emerging advantages of HDL-apoE3 over HDL-apoA-I, support the potential of rHDL-apoE3 in combating atherosclerosis. Novel rHDL formulations containing apoE3, either used alone or in combination with apoA-I, could possibly present enhanced atheroprotective functions. Further studies are now needed to assess the full potential of rHDL-apoE3 in vitro and in vivo.

Funding: This research was funded in the context of the project "In vitro and in vivo evaluation of the atheroprotective role of reconstituted HDL containing apolipoprotein E3" (MIS 5006782) under the call for proposals "Supporting researchers with emphasis on new researchers" (EDULLL 34). The project is co-financed by Greece and the European Union (European Social Fund- ESF) by the Operational Programme Human Resources Development, Education and Lifelong Learning 2014-2020.

Acknowledgments: We are grateful to Kardassis Dimitris for his constructive input towards the preparation of this manuscript.

Conflicts of Interest: The authors declare no conflict of interest.

\section{References}

1. Mozaffarian, D.; Benjamin, E.J.; Go, A.S.; Arnett, D.K.; Blaha, M.J.; Cushman, M.; de Ferranti, S.; Després, J.-P.; Fullerton, H.J.; Howard, V.J.; et al. Heart disease and stroke statistics-2015 update: A report from the American Heart Association. Circulation 2015, 131, e29-e322. [CrossRef] [PubMed]

2. Mozaffarian, D.; Benjamin, E.J.; Go, A.S.; Arnett, D.K.; Blaha, M.J.; Cushman, M.; Das, S.R.; de Ferranti, S.; Després, J.-P.; Fullerton, H.J.; et al. Stroke Statistics Subcommittee executive summary: Heart disease and stroke statistics-2016 Update: A report from the American Heart Association. Circulation 2016, 133, 447-454. [CrossRef] [PubMed]

3. Lusis, A.J. Atherosclerosis. Nature 2000, 407, 233-241. [CrossRef] [PubMed]

4. Harrison, D.G. Endothelial dysfunction in atherosclerosis. Basic Res. Cardiol. 1994, 89, 87-102. [PubMed]

5. Geng, S.; Chen, K.; Yuan, R.; Peng, L.; Maitra, U.; Diao, N.; Chen, C.; Zhang, Y.; Hu, Y.; Qi, C.-F.; et al. The persistence of low-grade inflammatory monocytes contributes to aggravated atherosclerosis. Nat. Commun. 2016, 7, 13436. [CrossRef] [PubMed]

6. Kandaswamy, E.; Zuo, L. Recent advances in treatment of coronary artery disease: Role of science and technology. Int. J. Mol. Sci. 2018, 19. [CrossRef] [PubMed]

7. Bhatt, A.; Rohatgi, A. HDL Cholesterol efflux capacity: Cardiovascular risk factor and potential therapeutic target. Curr. Atheroscler. Rep. 2016, 18, 2. [CrossRef] [PubMed]

8. Sabatine, M.S.; Giugliano, R.P.; Keech, A.C.; Honarpour, N.; Wiviott, S.D.; Murphy, S.A.; Kuder, J.F.; Wang, H.; Liu, T.; Wasserman, S.M.; et al. Evolocumab and clinical outcomes in patients with cardiovascular disease. N. Engl. J. Med. 2017, 376, 1713-1722. [CrossRef] [PubMed]

9. Reiner, Z. Resistance and intolerance to statins. Nutr. Metab. Cardiovasc. Dis. NMCD 2014, 24, 1057-1066. [CrossRef] [PubMed] 
10. Messas, N.; Dubé, M.-P.; Tardif, J.-C. Pharmacogenetics of lipid-lowering agents: An update review on genotype-dependent effects of HDL-targeting and statin therapies. Curr. Atheroscler. Rep. 2017, 19, 43. [CrossRef] [PubMed]

11. Karalis, I.; Jukema, J.W. HDL Mimetics infusion and regression of atherosclerosis: Is it still considered a valid therapeutic option? Curr. Cardiol. Rep. 2018, 20, 66. [CrossRef] [PubMed]

12. Cholesterol Treatment Trialists' (CTT) Collaboration; Baigent, C.; Blackwell, L.; Emberson, J.; Holland, L.E.; Reith, C.; Bhala, N.; Peto, R.; Barnes, E.H.; Keech, A.; et al. Efficacy and safety of more intensive lowering of LDL cholesterol: A meta-analysis of data from 170,000 participants in 26 randomised trials. Lancet Lond. Engl. 2010, 376, 1670-1681. [CrossRef]

13. Mancini, G.B.J.; Baker, S.; Bergeron, J.; Fitchett, D.; Frohlich, J.; Genest, J.; Gupta, M.; Hegele, R.A.; Ng, D.; Pearson, G.J.; et al. Diagnosis, prevention, and management of statin adverse effects and intolerance: Canadian Consensus Working Group Update (2016). Can. J. Cardiol. 2016, 32, S35-S65. [CrossRef] [PubMed]

14. Tardif, J.-C.; Rhéaume, E.; Lemieux Perreault, L.-P.; Grégoire, J.C.; Feroz Zada, Y.; Asselin, G.; Provost, S.; Barhdadi, A.; Rhainds, D.; L'Allier, P.L.; et al. Pharmacogenomic determinants of the cardiovascular effects of dalcetrapib. Circ. Cardiovasc. Genet. 2015, 8, 372-382. [CrossRef] [PubMed]

15. Tardif, J.-C.; Rhainds, D.; Rhéaume, E.; Dubé, M.-P. CETP: Pharmacogenomics-based response to the CETP inhibitor dalcetrapib. Arterioscler. Thromb. Vasc. Biol. 2017, 37, 396-400. [CrossRef] [PubMed]

16. Karalis, D.G.; Victor, B.; Ahedor, L.; Liu, L. Use of lipid-lowering medications and the likelihood of achieving optimal LDL-cholesterol goals in coronary artery disease patients. Cholesterol 2012, 2012, 861924. [CrossRef] [PubMed]

17. Sampson, U.K.; Fazio, S.; Linton, M.F. Residual cardiovascular risk despite optimal LDL cholesterol reduction with statins: The evidence, etiology, and therapeutic challenges. Curr. Atheroscler. Rep. 2012, 14, 1-10. [CrossRef] [PubMed]

18. Perrone, V.; Sangiorgi, D.; Buda, S.; Degli Esposti, L. Residual cardiovascular risk in patients who received lipid-lowering treatment in a real-life setting: Retrospective study. Clin. Outcomes Res. CEOR 2016, 8, 649-655. [CrossRef] [PubMed]

19. LaRosa, J.C.; Grundy, S.M.; Waters, D.D.; Shear, C.; Barter, P.; Fruchart, J.-C.; Gotto, A.M.; Greten, H.; Kastelein, J.J.P.; Shepherd, J.; et al. Intensive lipid lowering with atorvastatin in patients with stable coronary disease. N. Engl. J. Med. 2005, 352, 1425-1435. [CrossRef] [PubMed]

20. Fruchart, J.-C.; Sacks, F.M.; Hermans, M.P.; Assmann, G.; Brown, W.V.; Ceska, R.; Chapman, M.J.; Dodson, P.M.; Fioretto, P.; Ginsberg, H.N.; et al. The Residual Risk Reduction Initiative: A call to action to reduce residual vascular risk in dyslipidaemic patient. Diab. Vasc. Dis. Res. 2008, 5, 319-335. [CrossRef] [PubMed]

21. Mäkinen, P.I.; Ylä-Herttuala, S. Therapeutic gene targeting approaches for the treatment of dyslipidemias and atherosclerosis. Curr. Opin. Lipidol. 2013, 24, 116-122. [CrossRef] [PubMed]

22. Goveia, J.; Stapor, P.; Carmeliet, P. Principles of targeting endothelial cell metabolism to treat angiogenesis and endothelial cell dysfunction in disease. EMBO Mol. Med. 2014, 6, 1105-1120. [CrossRef] [PubMed]

23. Kumar, S.; Kim, C.W.; Simmons, R.D.; Jo, H. Role of flow-sensitive microRNAs in endothelial dysfunction and atherosclerosis: Mechanosensitive athero-miRs. Arterioscler. Thromb. Vasc. Biol. 2014, 34, 2206-2216. [CrossRef] [PubMed]

24. Kearney, M.T. Targeting the endothelium to prevent diabetes-related atherosclerosis. Diab. Vasc. Dis. Res. 2010, 7, 177. [CrossRef] [PubMed]

25. Darabi, M.; Guillas-Baudouin, I.; Le Goff, W.; Chapman, M.J.; Kontush, A. Therapeutic applications of reconstituted HDL: When structure meets function. Pharmacol. Ther. 2016, 157, 28-42. [CrossRef] [PubMed]

26. Rosenson, R.S.; Brewer, H.B.; Ansell, B.J.; Barter, P.; Chapman, M.J.; Heinecke, J.W.; Kontush, A.; Tall, A.R.; Webb, N.R. Dysfunctional HDL and atherosclerotic cardiovascular disease. Nat. Rev. Cardiol. 2016, 13, 48-60. [CrossRef] [PubMed]

27. Hoekstra, M.; Van Berkel, T.J.C. Functionality of high-density lipoprotein as antiatherosclerotic therapeutic target. Arterioscler. Thromb. Vasc. Biol. 2016, 36, e87-e94. [CrossRef] [PubMed]

28. Ossoli, A.; Pavanello, C.; Giorgio, E.; Calabresi, L.; Gomaraschi, M. Dysfunctional HDL as a therapeutic target for atherosclerosis prevention. Curr. Med. Chem. 2018. [CrossRef] [PubMed]

29. Kypreos, K.E.; Gkizas, S.; Rallidis, L.S.; Karagiannides, I. HDL particle functionality as a primary pharmacological target for HDL-based therapies. Biochem. Pharmacol. 2013, 85, 1575-1578. [CrossRef] [PubMed] 
30. Rosales, C.; Davidson, W.S.; Gillard, B.K.; Gotto, A.M.; Pownall, H.J. Speciated high-density lipoprotein biogenesis and functionality. Curr. Atheroscler. Rep. 2016, 18, 25. [CrossRef] [PubMed]

31. Schwartz, G.G.; Olsson, A.G.; Abt, M.; Ballantyne, C.M.; Barter, P.J.; Brumm, J.; Chaitman, B.R.; Holme, I.M.; Kallend, D.; Leiter, L.A.; et al. Effects of dalcetrapib in patients with a recent acute coronary syndrome. N. Engl. J. Med. 2012, 367, 2089-2099. [CrossRef] [PubMed]

32. Van Capelleveen, J.C.; Brewer, H.B.; Kastelein, J.J.P.; Hovingh, G.K. Novel therapies focused on the high-density lipoprotein particle. Circ. Res. 2014, 114, 193-204. [CrossRef] [PubMed]

33. Zannis, V.; Kateifides, A.; Fotakis, P.; Zanni, E.; Kardassis, D. Pleiotropic Functions of HDL Lead to Protection from Atherosclerosis and Other Diseases. In Dyslipidemia-From Prevention to Treatment; Kelishadi, R., Ed.; IntechOpen: London, UK, 2012. [CrossRef]

34. Rosenson, R.S.; Brewer, H.B.; Ansell, B.; Barter, P.; Chapman, M.J.; Heinecke, J.W.; Kontush, A.; Tall, A.R.; Webb, N.R. Translation of high-density lipoprotein function into clinical practice: Current prospects and future challenges. Circulation 2013, 128, 1256-1267. [CrossRef] [PubMed]

35. Noor, R.; Shuaib, U.; Wang, C.X.; Todd, K.; Ghani, U.; Schwindt, B.; Shuaib, A. High-density lipoprotein cholesterol regulates endothelial progenitor cells by increasing eNOS and preventing apoptosis. Atherosclerosis 2007, 192, 92-99. [CrossRef] [PubMed]

36. Hughes, S.D.; Verstuyft, J.; Rubin, E.M. HDL deficiency in genetically engineered mice requires elevated LDL to accelerate atherogenesis. Arterioscler. Thromb. Vasc. Biol. 1997, 17, 1725-1729. [CrossRef] [PubMed]

37. Tangirala, R.K.; Tsukamoto, K.; Chun, S.H.; Usher, D.; Puré, E.; Rader, D.J. Regression of atherosclerosis induced by liver-directed gene transfer of apolipoprotein A-I in mice. Circulation 1999, 100, 1816-1822. [CrossRef] [PubMed]

38. Wilhelm, A.J.; Zabalawi, M.; Owen, J.S.; Shah, D.; Grayson, J.M.; Major, A.S.; Bhat, S.; Gibbs, D.P.; Thomas, M.J.; Sorci-Thomas, M.G. Apolipoprotein A-I modulates regulatory T cells in autoimmune LDLr ${ }^{-/-}$, ApoA-I ${ }^{-/-}$mice. J. Biol. Chem. 2010, 285, 36158-36169. [CrossRef] [PubMed]

39. Wang, X.; Collins, H.L.; Ranalletta, M.; Fuki, I.V.; Billheimer, J.T.; Rothblat, G.H.; Tall, A.R.; Rader, D.J. Macrophage ABCA1 and ABCG1, but not SR-BI, promote macrophage reverse cholesterol transport in vivo. J. Clin. Invest. 2007, 117, 2216-2224. [CrossRef] [PubMed]

40. Bursill, C.A.; Castro, M.L.; Beattie, D.T.; Nakhla, S.; van der Vorst, E.; Heather, A.K.; Barter, P.J.; Rye, K.-A. High-density lipoproteins suppress chemokines and chemokine receptors in vitro and in vivo. Arterioscler. Thromb. Vasc. Biol. 2010, 30, 1773-1778. [CrossRef] [PubMed]

41. Cockerill, G.W.; Rye, K.A.; Gamble, J.R.; Vadas, M.A.; Barter, P.J. High-density lipoproteins inhibit cytokine-induced expression of endothelial cell adhesion molecules. Arterioscler. Thromb. Vasc. Biol. 1995, 15, 1987-1994. [CrossRef] [PubMed]

42. Nobécourt, E.; Tabet, F.; Lambert, G.; Puranik, R.; Bao, S.; Yan, L.; Davies, M.J.; Brown, B.E.; Jenkins, A.J.; Dusting, G.J.; et al. Nonenzymatic glycation impairs the antiinflammatory properties of apolipoprotein A-I. Arterioscler. Thromb. Vasc. Biol. 2010, 30, 766-772. [CrossRef] [PubMed]

43. Seetharam, D.; Mineo, C.; Gormley, A.K.; Gibson, L.L.; Vongpatanasin, W.; Chambliss, K.L.; Hahner, L.D.; Cummings, M.L.; Kitchens, R.L.; Marcel, Y.L.; et al. High-density lipoprotein promotes endothelial cell migration and reendothelialization via scavenger receptor-B type I. Circ. Res. 2006, 98, 63-72. [CrossRef] [PubMed]

44. Suc, I.; Escargueil-Blanc, I.; Troly, M.; Salvayre, R.; Nègre-Salvayre, A. HDL and ApoA prevent cell death of endothelial cells induced by oxidized LDL. Arterioscler. Thromb. Vasc. Biol. 1997, 17, 2158-2166. [CrossRef] [PubMed]

45. De Souza, J.A.; Vindis, C.; Nègre-Salvayre, A.; Rye, K.-A.; Couturier, M.; Therond, P.; Chantepie, S.; Salvayre, R.; Chapman, M.J.; Kontush, A. Small, dense HDL 3 particles attenuate apoptosis in endothelial cells: Pivotal role of apolipoprotein A-I. J. Cell. Mol. Med. 2010, 14, 608-620. [CrossRef] [PubMed]

46. Radojkovic, C.; Genoux, A.; Pons, V.; Combes, G.; de Jonge, H.; Champagne, E.; Rolland, C.; Perret, B.; Collet, X.; Tercé, F.; Martinez, L.O. Stimulation of cell surface F1-ATPase activity by apolipoprotein A-I inhibits endothelial cell apoptosis and promotes proliferation. Arterioscler. Thromb. Vasc. Biol. 2009, 29, 1125-1130. [CrossRef] [PubMed]

47. Javaheri, A.; Kolansky, D.M.; Cuchel, M. Reconstituted high-density lipoprotein therapies: A cause for optimism. Arterioscler. Thromb. Vasc. Biol. 2014, 34, 1800-1802. [CrossRef] [PubMed]

48. White, C.R.; Garber, D.W.; Anantharamaiah, G.M. Anti-inflammatory and cholesterol-reducing properties of apolipoprotein mimetics: A review. J. Lipid Res. 2014, 55, 2007-2021. [CrossRef] [PubMed] 
49. Kingwell, B.A.; Chapman, M.J.; Kontush, A.; Miller, N.E. HDL-targeted therapies: Progress, failures and future. Nat. Rev. Drug Discov. 2014, 13, 445-464. [CrossRef] [PubMed]

50. Tricoci, P.; D'Andrea, D.M.; Gurbel, P.A.; Yao, Z.; Cuchel, M.; Winston, B.; Schott, R.; Weiss, R.; Blazing, M.A.; Cannon, L.; et al. Infusion of reconstituted high-density lipoprotein, CSL112, in patients with atherosclerosis: Safety and pharmacokinetic results from a phase 2a randomized clinical trial. J. Am. Heart Assoc. 2015, 4, e002171. [CrossRef] [PubMed]

51. Marsche, G. It's time to reassess the high-density lipoprotein (HDL) hypothesis: CSL112, a novel promising reconstituted HDL formulation. J. Am. Heart Assoc. 2015, 4, e002371. [CrossRef] [PubMed]

52. Kempen, H.J.; Gomaraschi, M.; Simonelli, S.; Calabresi, L.; Moerland, M.; Otvos, J.; Jeyarajah, E.; Kallend, D.; Wijngaard, P.L.J. Persistent changes in lipoprotein lipids after a single infusion of ascending doses of MDCO-216 (apoA-IMilano/POPC) in healthy volunteers and stable coronary artery disease patients. Atherosclerosis 2016, 255, 17-24. [CrossRef] [PubMed]

53. Tardif, J.-C.; Ballantyne, C.M.; Barter, P.; Dasseux, J.-L.; Fayad, Z.A.; Guertin, M.-C.; Kastelein, J.J.P.; Keyserling, C.; Klepp, H.; Koenig, W.; et al. Effects of the high-density lipoprotein mimetic agent CER-001 on coronary atherosclerosis in patients with acute coronary syndromes: A randomized trial. Eur. Heart J. 2014, 35, 3277-3286. [CrossRef] [PubMed]

54. Easton, R.; Gille, A.; D'Andrea, D.; Davis, R.; Wright, S.D.; Shear, C. A multiple ascending dose study of CSL112, an infused formulation of ApoA-I. J. Clin. Pharmacol. 2014, 54, 301-310. [CrossRef] [PubMed]

55. Sirtori, C.R.; Calabresi, L.; Franceschini, G.; Baldassarre, D.; Amato, M.; Johansson, J.; Salvetti, M.; Monteduro, C.; Zulli, R.; Muiesan, M.L.; et al. Cardiovascular status of carriers of the apolipoprotein A-I $\mathrm{I}_{\text {Milano }}$ mutant: The Limone sul Garda study. Circulation 2001, 103, 1949-1954. [CrossRef] [PubMed]

56. Chenevard, R.; Hürlimann, D.; Spieker, L.; Béchir, M.; Enseleit, F.; Hermann, M.; Flammer, A.J.; Sudano, I.; Corti, R.; Lüscher, T.F.; et al. Reconstituted HDL in acute coronary syndromes. Cardiovasc. Ther. 2012, 30, e51-e57. [CrossRef] [PubMed]

57. Andrews, J.; Janssan, A.; Nguyen, T.; Pisaniello, A.D.; Scherer, D.J.; Kastelein, J.J.P.; Merkely, B.; Nissen, S.E.; Ray, K.; Schwartz, G.G.; et al. Effect of serial infusions of reconstituted high-density lipoprotein (CER-001) on coronary atherosclerosis: Rationale and design of the CARAT study. Cardiovasc. Diagn. Ther. 2017, 7, 45-51. [CrossRef] [PubMed]

58. Michael Gibson, C.; Korjian, S.; Tricoci, P.; Daaboul, Y.; Yee, M.; Jain, P.; Alexander, J.H.; Steg, P.G.; Lincoff, A.M.; Kastelein, J.J.P.; et al. Safety and Tolerability of CSL112, a Reconstituted, Infusible, Plasma-Derived Apolipoprotein A-I, After Acute Myocardial Infarction: The AEGIS-I Trial (ApoA-I Event Reducing in Ischemic Syndromes I). Circulation 2016, 134, 1918-1930. [CrossRef] [PubMed]

59. Ibanez, B.; Giannarelli, C.; Cimmino, G.; Santos-Gallego, C.G.; Alique, M.; Pinero, A.; Vilahur, G.; Fuster, V.; Badimon, L.; Badimon, J.J. Recombinant HDL Milano exerts greater anti-inflammatory and plaque stabilizing properties than $\mathrm{HDL}_{\text {wild-type }}$. Atherosclerosis 2012, 220, 72-77. [CrossRef] [PubMed]

60. Tardy, C.; Goffinet, M.; Boubekeur, N.; Cholez, G.; Ackermann, R.; Sy, G.; Keyserling, C.; Lalwani, N.; Paolini, J.F.; Dasseux, J.-L.; et al. HDL and CER-001 Inverse-Dose Dependent Inhibition of Atherosclerotic Plaque Formation in apoE ${ }^{-/-}$Mice: Evidence of ABCA1 Down-Regulation. PLoS ONE 2015, 10, e0137584. [CrossRef] [PubMed]

61. Kootte, R.S.; Smits, L.P.; van der Valk, F.M.; Dasseux, J.-L.; Keyserling, C.H.; Barbaras, R.; Paolini, J.F.; Santos, R.D.; van Dijk, T.H.; Dallinga-van Thie, G.M.; et al. Effect of open-label infusion of an apoA-I-containing particle (CER-001) on RCT and artery wall thickness in patients with FHA. J. Lipid Res. 2015, 56, 703-712. [CrossRef] [PubMed]

62. Hovingh, G.K.; Smits, L.P.; Stefanutti, C.; Soran, H.; Kwok, S.; de Graaf, J.; Gaudet, D.; Keyserling, C.H.; Klepp, H.; Frick, J.; et al. The effect of an apolipoprotein A-I-containing high-density lipoprotein-mimetic particle (CER-001) on carotid artery wall thickness in patients with homozygous familial hypercholesterolemia: The Modifying Orphan Disease Evaluation (MODE) study. Am. Heart J. 2015, 169, 736-742. [CrossRef] [PubMed]

63. Greenow, K.; Pearce, N.J.; Ramji, D.P. The key role of apolipoprotein E in atherosclerosis. J. Mol. Med. 2005, 83, 329-342. [CrossRef] [PubMed]

64. Rosenfeld, M.E.; Butler, S.; Ord, V.A.; Lipton, B.A.; Dyer, C.A.; Curtiss, L.K.; Palinski, W.; Witztum, J.L. Abundant expression of apoprotein $\mathrm{E}$ by macrophages in human and rabbit atherosclerotic lesions. Arterioscler. Thromb. J. Vasc. Biol. 1993, 13, 1382-1389. [CrossRef] 
65. Mahley, R.W. Apolipoprotein E: From cardiovascular disease to neurodegenerative disorders. J. Mol. Med. Berl. Ger. 2016, 94, 739-746. [CrossRef] [PubMed]

66. Bennet, A.M.; Di Angelantonio, E.; Ye, Z.; Wensley, F.; Dahlin, A.; Ahlbom, A.; Keavney, B.; Collins, R.; Wiman, B.; de Faire, U.; et al. Association of apolipoprotein E genotypes with lipid levels and coronary risk. JAMA 2007, 298, 1300-1311. [CrossRef] [PubMed]

67. Song, Y.; Stampfer, M.J.; Liu, S. Meta-analysis: Apolipoprotein E genotypes and risk for coronary heart disease. Ann. Intern. Med. 2004, 141, 137-147. [CrossRef] [PubMed]

68. Zhang, Y.; Tang, H.-Q.; Peng, W.-J.; Zhang, B.-B.; Liu, M. Meta-analysis for the Association of Apolipoprotein E $\varepsilon 2 / \varepsilon 3 / \varepsilon 4$ Polymorphism with Coronary Heart Disease. Chin. Med. J. (Engl.) 2015, 128, 1391-1398. [CrossRef] [PubMed]

69. Linton, M.F.; Hasty, A.H.; Babaev, V.R.; Fazio, S. Hepatic apo E expression is required for remnant lipoprotein clearance in the absence of the low density lipoprotein receptor. J. Clin. Invest. 1998, 101, 1726-1736. [CrossRef] [PubMed]

70. Mahley, R.W.; Ji, Z.S. Remnant lipoprotein metabolism: Key pathways involving cell-surface heparan sulfate proteoglycans and apolipoprotein E. J. Lipid Res. 1999, 40, 1-16. [PubMed]

71. Kypreos, K.E.; Zannis, V.I. LDL receptor deficiency or apoE mutations prevent remnant clearance and induce hypertriglyceridemia in mice. J. Lipid Res. 2006, 47, 521-529. [CrossRef] [PubMed]

72. Schaefer, E.J.; Gregg, R.E.; Ghiselli, G.; Forte, T.M.; Ordovas, J.M.; Zech, L.A.; Brewer, H.B. Familial apolipoprotein E deficiency. J. Clin. Investig. 1986, 78, 1206-1219. [CrossRef] [PubMed]

73. Zhang, S.H.; Reddick, R.L.; Piedrahita, J.A.; Maeda, N. Spontaneous hypercholesterolemia and arterial lesions in mice lacking apolipoprotein E. Science 1992, 258, 468-471. [CrossRef] [PubMed]

74. Desurmont, C.; Caillaud, J.M.; Emmanuel, F.; Benoit, P.; Fruchart, J.C.; Castro, G.; Branellec, D.; Heard, J.M.; Duverger, N. Complete atherosclerosis regression after human ApoE gene transfer in ApoE-deficient/nude mice. Arterioscler. Thromb. Vasc. Biol. 2000, 20, 435-442. [CrossRef] [PubMed]

75. Kuipers, F.; Jong, M.C.; Lin, Y.; Eck, M.; Havinga, R.; Bloks, V.; Verkade, H.J.; Hofker, M.H.; Moshage, H.; Berkel, T.J.; et al. Impaired secretion of very low density lipoprotein-triglycerides by apolipoprotein Edeficient mouse hepatocytes. J. Clin. Investig. 1997, 100, 2915-2922. [CrossRef] [PubMed]

76. Cullen, P.; Cignarella, A.; Brennhausen, B.; Mohr, S.; Assmann, G.; von Eckardstein, A. Phenotype-dependent differences in apolipoprotein E metabolism and in cholesterol homeostasis in human monocyte-derived macrophages. J. Clin. Investig. 1998, 101, 1670-1677. [CrossRef] [PubMed]

77. Hayek, T.; Oiknine, J.; Brook, J.G.; Aviram, M. Role of HDL apolipoprotein E in cellular cholesterol efflux: Studies in apo E knockout transgenic mice. Biochem. Biophys. Res. Commun. 1994, 205, 1072-1078. [CrossRef] [PubMed]

78. Zhu, Y.; Bellosta, S.; Langer, C.; Bernini, F.; Pitas, R.E.; Mahley, R.W.; Assmann, G.; von Eckardstein, A. Low-dose expression of a human apolipoprotein $\mathrm{E}$ transgene in macrophages restores cholesterol efflux capacity of apolipoprotein E-deficient mouse plasma. Proc. Natl. Acad. Sci. USA 1998, 95, 7585-7590. [CrossRef] [PubMed]

79. Kypreos, K.E.; Zannis, V.I. Pathway of biogenesis of apolipoprotein E-containing HDL in vivo with the participation of ABCA1 and LCAT. Biochem. J. 2007, 403, 359-367. [CrossRef] [PubMed]

80. Filou, S.; Lhomme, M.; Karavia, E.A.; Kalogeropoulou, C.; Theodoropoulos, V.; Zvintzou, E.; Sakellaropoulos, G.C.; Petropoulou, P.-I.; Constantinou, C.; Kontush, A.; et al. Distinct Roles of Apolipoproteins A1 and E in the Modulation of High-Density Lipoprotein Composition and Function. Biochemistry 2016, 55, 3752-3762. [CrossRef] [PubMed]

81. Thuren, T.; Weisgraber, K.H.; Sisson, P.; Waite, M. Role of apolipoprotein E in hepatic lipase catalyzed hydrolysis of phospholipid in high-density lipoproteins. Biochemistry 1992, 31, 2332-2338. [CrossRef] [PubMed]

82. Kinoshita, M.; Arai, H.; Fukasawa, M.; Watanabe, T.; Tsukamoto, K.; Hashimoto, Y.; Inoue, K.; Kurokawa, K.; Teramoto, T. Apolipoprotein E enhances lipid exchange between lipoproteins mediated by cholesteryl ester transfer protein. J. Lipid Res. 1993, 34, 261-268. [PubMed]

83. De Pauw, M.; Vanloo, B.; Weisgraber, K.; Rosseneu, M. Comparison of lipid-binding and lecithin:cholesterol acyltransferase activation of the amino- and carboxyl-terminal domains of human apolipoprotein E3. Biochemistry 1995, 34, 10953-10966. [CrossRef] [PubMed]

84. Stannard, A.K.; Riddell, D.R.; Sacre, S.M.; Tagalakis, A.D.; Langer, C.; von Eckardstein, A.; Cullen, P.; Athanasopoulos, T.; Dickson, G.; Owen, J.S. Cell-derived apolipoprotein E (ApoE) particles inhibit vascular cell 
adhesion molecule-1 (VCAM-1) expression in human endothelial cells. J. Biol. Chem. 2001, 276, 46011-46016. [CrossRef] [PubMed]

85. Sacre, S.M.; Stannard, A.K.; Owen, J.S. Apolipoprotein E (apoE) isoforms differentially induce nitric oxide production in endothelial cells. FEBS Lett. 2003, 540, 181-187. [CrossRef]

86. Ulrich, V.; Konaniah, E.S.; Herz, J.; Gerard, R.D.; Jung, E.; Yuhanna, I.S.; Ahmed, M.; Hui, D.Y.; Mineo, C.; Shaul, P.W. Genetic variants of ApoE and ApoER2 differentially modulate endothelial function. Proc. Natl. Acad. Sci. USA 2014, 111, 13493-13498. [CrossRef] [PubMed]

87. Kelly, M.E.; Clay, M.A.; Mistry, M.J.; Hsieh-Li, H.M.; Harmony, J.A. Apolipoprotein E inhibition of proliferation of mitogen-activated T lymphocytes: Production of interleukin 2 with reduced biological activity. Cell. Immunol. 1994, 159, 124-139. [CrossRef] [PubMed]

88. Swertfeger, D.K.; Hui, D.Y. Apolipoprotein E receptor binding versus heparan sulfate proteoglycan binding in its regulation of smooth muscle cell migration and proliferation. J. Biol. Chem. 2001, 276, 25043-25048. [CrossRef] [PubMed]

89. Palinski, W.; Ord, V.A.; Plump, A.S.; Breslow, J.L.; Steinberg, D.; Witztum, J.L. ApoE-deficient mice are a model of lipoprotein oxidation in atherogenesis. Demonstration of oxidation-specific epitopes in lesions and high titers of autoantibodies to malondialdehyde-lysine in serum. Arterioscler. Thromb. J. Vasc. Biol. 1994, 14, 605-616. [CrossRef]

90. Riddell, D.R.; Graham, A.; Owen, J.S. Apolipoprotein E inhibits platelet aggregation through the L-arginine:nitric oxide pathway. Implications for vascular disease. J. Biol. Chem. 1997, 272, 89-95. [CrossRef] [PubMed]

91. Li, K.; Ching, D.; Luk, F.S.; Raffai, R.L. Apolipoprotein E enhances microRNA-146a in monocytes and macrophages to suppress nuclear factor-kB-driven inflammation and atherosclerosis. Circ. Res. 2015, 117, e1-e11. [CrossRef] [PubMed]

92. DeKroon, R.M.; Mihovilovic, M.; Goodger, Z.V.; Robinette, J.B.; Sullivan, P.M.; Saunders, A.M.; Strittmatter, W.J. ApoE genotype-specific inhibition of apoptosis. J. Lipid Res. 2003, 44, 1566-1573. [CrossRef] [PubMed]

93. Datta, G.; White, C.R.; Dashti, N.; Chaddha, M.; Palgunachari, M.N.; Gupta, H.; Handattu, S.P.; Garber, D.W.; Anantharamaiah, G.M. Anti-inflammatory and recycling properties of an apolipoprotein mimetic peptide, Ac-hE18A-NH ${ }_{2}$. Atherosclerosis 2010, 208, 134-141. [CrossRef] [PubMed]

94. Gupta, H.; White, C.R.; Handattu, S.; Garber, D.W.; Datta, G.; Chaddha, M.; Dai, L.; Gianturco, S.H.; Bradley, W.A.; Anantharamaiah, G.M. Apolipoprotein E mimetic Peptide dramatically lowers plasma cholesterol and restores endothelial function in Watanabe heritable hyperlipidemic rabbits. Circulation 2005, 111, 3112-3118. [CrossRef] [PubMed]

95. Handattu, S.P.; Nayyar, G.; Garber, D.W.; Palgunachari, M.N.; Monroe, C.E.; Keenum, T.D.; Mishra, V.K.; Datta, G.; Anantharamaiah, G.M. Two apolipoprotein E mimetic peptides with similar cholesterol reducing properties exhibit differential atheroprotective effects in LDL-R null mice. Atherosclerosis 2013, 227, 58-64. [CrossRef] [PubMed]

96. Plump, A.S.; Smith, J.D.; Hayek, T.; Aalto-Setälä, K.; Walsh, A.; Verstuyft, J.G.; Rubin, E.M.; Breslow, J.L. Severe hypercholesterolemia and atherosclerosis in apolipoprotein E-deficient mice created by homologous recombination in ES cells. Cell 1992, 71, 343-353. [CrossRef]

97. Li, H.; Reddick, R.L.; Maeda, N. Lack of apoA-I is not associated with increased susceptibility to atherosclerosis in mice. Arterioscler. Thromb. J. Vasc. Biol. 1993, 13, 1814-1821. [CrossRef]

98. Trigatti, B.; Rayburn, H.; Viñals, M.; Braun, A.; Miettinen, H.; Penman, M.; Hertz, M.; Schrenzel, M.; Amigo, L.; Rigotti, A.; et al. Influence of the high density lipoprotein receptor SR-BI on reproductive and cardiovascular pathophysiology. Proc. Natl. Acad. Sci. USA 1999, 96, 9322-9327. [CrossRef] [PubMed]

99. Braun, A.; Trigatti, B.L.; Post, M.J.; Sato, K.; Simons, M.; Edelberg, J.M.; Rosenberg, R.D.; Schrenzel, M.; Krieger, M. Loss of SR-BI expression leads to the early onset of occlusive atherosclerotic coronary artery disease, spontaneous myocardial infarctions, severe cardiac dysfunction, and premature death in apolipoprotein E-deficient mice. Circ. Res. 2002, 90, 270-276. [CrossRef] [PubMed]

100. Gonzalez, L.; Yu, P.; Trigatti, B.L. Mouse Models of Coronary Artery Atherosclerosis. J Cardiovasc. Disord. 2016, 3, 1021. 
101. Nakashima, Y.; Plump, A.S.; Raines, E.W.; Breslow, J.L.; Ross, R. ApoE-deficient mice develop lesions of all phases of atherosclerosis throughout the arterial tree. Arterioscler. Thromb. J. Vasc. Biol. 1994, 14, 133-140. [CrossRef]

102. Van Eck, M.; Twisk, J.; Hoekstra, M.; Van Rij, B.T.; Van der Lans, C.A.C.; Bos, I.S.T.; Kruijt, J.K.; Kuipers, F.; Van Berkel, T.J.C. Differential effects of scavenger receptor BI deficiency on lipid metabolism in cells of the arterial wall and in the liver. J. Biol. Chem. 2003, 278, 23699-23705. [CrossRef] [PubMed]

103. Chroni, A.; Nieland, T.J.F.; Kypreos, K.E.; Krieger, M.; Zannis, V.I. SR-BI mediates cholesterol efflux via its interactions with lipid-bound ApoE. Structural mutations in SR-BI diminish cholesterol efflux. Biochemistry 2005, 44, 13132-13143. [CrossRef] [PubMed]

(C) 2018 by the authors. Licensee MDPI, Basel, Switzerland. This article is an open access article distributed under the terms and conditions of the Creative Commons Attribution (CC BY) license (http:/ / creativecommons.org/licenses/by/4.0/). 